\title{
The sustainable development effects of investment by emerging-market multinationals: shaping beneficial outcomes for home and host country
}

\author{
Guus Hendriks*
}

Emerging-market multinational enterprises (EMNEs) play an increasingly important role as investors in developing economies. When certain conditions are met, their foreign investment can contribute to host-country progress towards the Sustainable Development Goals (SDGs). Moreover, foreign investment by EMNEs could also bring positive development effects for the home economies from which they internationalize. However, some concern exists about the possibility that gains will not be equitably shared or that potential will be not realized in one or the other. This article aims to shed light on the conditions that will allow both the home country of an EMNE and the host country receiving its investment to make progress towards the SDGs. Five areas for policy action are presented, together with a research agenda. It is argued that the most promising measures encourage foreign investment to be long-term, stimulate linkages between EMNEs' home-country partners and hosteconomy firms, incentivize home- and host-country firms to take on new roles within global value chains, capitalize on institutional upgrading potential and tie certain conditions to the right to access natural resources. Both home and host countries could then potentially benefit from EMNEs' outward investment and make progress on goals related to poverty alleviation (SDG 1), economic growth and the creation of decent work (SDG 8), infrastructure development (SDG 9) and institutional upgrading (SDG 16).

\section{Introduction}

Foreign direct investment (FDI) is often considered as a powerful means for supplying developing economies with much-needed funds and expertise, setting processes in motion that will allow such countries to make progress in terms of development. Indeed, research has shown that developing economies may benefit from inward investment when conditions are right, fuelling belief in an FDI-assisted development

* Guus Hendriks is at the Department of Strategic Management and Entrepreneurship, Rotterdam School of Management, Erasmus University Rotterdam, Netherlands. Contact: hendriks@rsm.nl 
strategy (Narula and Dunning, 2010). Foreign investment could thus potentially be an instrument with which multinational enterprises (MNEs) contribute to the Sustainable Development Goals (SDGs) (Kolk, 2016). The most promising areas in which progress can be made include poverty alleviation (SDG 1) and the creation of decent work opportunities through inclusive economic growth (SDG 8). That is, foreign investment has the potential to spur economic activity either directly or indirectly through realized spillover effects (Blomström and Kokko, 1998).

Whereas such thinking is shaped primarily by the investment behaviour of firms from developed countries, recent decades reflect a reality in which MNEs from emerging markets (EMNEs) have become increasingly important investors worldwide (Chen and Johnson, 2013). Although classification systems vary, EMNEs are generally considered to be firms from countries that share certain characteristics with developed markets but cannot be fully considered as such (CCSI, 2016). Hence, internationally active firms from countries such as China, India, Mexico and Argentina would typically be classified as EMNEs. As a sign of their growing importance, such firms possessed almost a quarter of the world's total outward FDI stock in 2015 (UNCTAD, 2016). Corresponding with that changing landscape is a different composition of firms that invest in less-developed countries. Increasingly frequently, EMNEs undertake large investment projects in countries that are less developed than their respective home countries, whereby their investment behaviour is often judged to differ from that of their developed-economy counterparts. Specifically, EMNEs' international investment patterns are strongly influenced by their home environments, which may relate to government involvement, but also to the way they navigate challenging institutional settings. Their experience with environments in which institutions are absent or inferior and with ways to cope with such situations gives them an advantage over developed-economy MNEs when they invest in other developing countries that are similarly characterized by a lack of institutional quality (Cuervo-Cazurra and Genc, 2008).

From a sustainable development perspective, such investment is particularly interesting, as not only could the host country potentially benefit, but also the home economy. Although substantial progress has already been made in countries such as China and India, much potential remains to lift even more people above the poverty threshold and have growth become more inclusive. However, the literature on the development effects of foreign investment, in relation to both the home and host country, is far from conclusive (e.g., Narula, 2014; Blomström and Kokko, 1998). Unless certain conditions are met, development effects may not materialize, raising concerns that gains from EMNEs' foreign investment may not be equitably shared between countries or that potential may be left unrealized. This article aims to shed light on the conditions that will allow both the home country of an EMNE and the host country receiving its investment to make progress on SDGs. After discussing what is known about the development effects of foreign investment and suggesting what 
is required in both countries for that investment to support SDGs, I derive five areas of policy action that are most promising in light of those goals. As the effects of such conditions remain largely unstudied, I present a research agenda in connection with each of the five areas.

\section{Foreign investment and development}

Although frequently heralded as a panacea for feeble economic development, conditions need to be right for foreign investment to have sustainable effects on host economies (Narula and Driffield, 2012). Such effects can be direct, for example in terms of creating employment, but also indirect when benefits from investment spill over to other firms in the host country, enabling them to upgrade their asset bundles owing to the improved access to superior technology and (managerial) skills (Blomström and Kokko, 1998). In turn, the extent to which spillover effects are realized relates to the ability of host-country firms to capitalize on the technology and knowledge that investors bring with them when they internationalize (Bell and Marin, 2004). A review of the FDI-development literature reveals five important factors that make it more likely that foreign investment will have a lasting effect on the host economy (Narula and Dunning, 2010).

First, developing countries need to attract the "right kind" of foreign investment in line with their short- and long-term goals. That is, not all types of investment have the potential to bring about long-term development effects. For example, FDI in low-skilled sectors of the economy may create jobs and help alleviate poverty in the short run, but long-term development goals are best achieved when there are opportunities for host-country firms to learn and upgrade (Narula and Dunning, 2000; Narula, 2014).

Second, the recipient country should have sufficient absorptive capacity to internalize potential gains from investment (Lorentzen, 2005). Although investing firms may have superior skills, knowledge and technology, the opportunity to benefit from such resource bundles will go to waste when host-economy firms are unable to connect them with their existing resource base (e.g., Konara and Wei, 2016).

Third, sustainable development gains can be realized when a group of firms in an industry is able to successfully carve out an important role within a global value chain (GVC) (Giuliani, Pietrobelli and Rabellotti, 2005). For example, South Africa's automotive industry managed to link into the global automotive value chain through the government's use of active industrial policy, fostering substantial upgrading (Barnes and Morris, 2008).

Fourth, linkages are seen as the key mechanism through which local firms in the host country can access the investor's superior knowledge and technology (Giroud, 2012; 
Castellani and Zanfei, 2012). For example, linkages are established when investor firms seek partners that help them navigate unfamiliar environments or when they cooperate with local suppliers. Backward linkages, which involve partners supplying inputs to investor firms, likely are more effective in generating spillovers than forward linkages, whereby the investor firm supplies intermediate inputs to domestic customers (Javorcik, 2004). Yet, investments that are not firmly rooted in the host environment, whereby the investing firm mainly relies on a supplier network back home, will generate few chances for local firms to upgrade and expand (Javorcik, 2004).

Fifth, even though host-country governments predominantly put measures in place to attract foreign investment, it is unlikely that such an influx of capital in the economy will have lasting effects unless it stays in the country for a prolonged period of time (Lall and Narula, 2004). The longevity of inward investment, therefore, determines to an important extent whether a host country is able to make progress on the SDGs. That is, it leads investing firms to become more embedded in host environments, and it allows local firms more time to climb the learning curve of upgrading. Although each of these factors can individually improve the chance that investment will have a sustainable impact on development in the host economy, simultaneous fulfilment of two or more such conditions is likely to have the strongest effect (Narula and Driffield, 2012).

\section{International investment by EMNEs}

Although knowledge about the relationship between foreign investment and development has been built up over an extended period of time, much of the evidence relates to developing countries that attract investment from western MNEs (Narula, 2014). However, EMNEs are increasingly important investors in developing economies, too (Chen and Johnson, 2013). For example, $75 \%$ of China's FDI stock, which totalled US\$789 billion in 2014, is invested in Asian developing economies (UNCTAD, 2016). Firms from emerging economies may more readily invest in developing countries as it allows entry into an environment in which they hold an advantage over developedeconomy rivals. That is, emerging as well as developing economies are often characterized by institutions that are comparatively underdeveloped, presenting firms with difficulties ranging from dense bureaucracy to an imperfect contracting environment (Cuervo-Cazurra and Genc, 2008). Experience navigating such environments can then be of use in other developing economies and give EMNEs a competitive edge (Khanna and Palepu, 2006; Cuervo-Cazurra and Genc, 2008).

When comparing EMNEs and their developed-economy counterparts, it becomes clear that investment patterns differ in many other ways (Guillén and Garcia-Canal, 2009). For example, home-country governments typically play a more important role for the internationalization trajectories of the former type of firms (Wang, Hong, 
Kafouros and Wright, 2012; Luo and Tung, 2007). Such influence may be more direct in the form of ownership stakes, but also include approval procedures, insurance schemes, loans and subsidies (Luo, Xue and Han, 2010). Governments are often seen to actively use such instruments as they "pick winners" and stimulate outward investment (Hemphill and White, 2013). In line with that observation is the notion that EMNEs often internationalize to strengthen their position back home (Williamson and Raman, 2011). Governments may motivate firms to secure natural resources not available in the home economy and further fuel such a strategy (Wang et al., 2012).

If EMNEs are indeed more concerned with their home market, perhaps as the result of home government involvement, outward investment may be followed by quick withdrawal upon the acquisition of natural resources or strategic assets. Yet, some EMNEs are also seen to take over roles otherwise played by transaction-facilitating institutions and even invest in infrastructure, such as roads and ports, with the long-term aim of securing access to resources (Doh, Rodrigues, Saka-Helmhout and Makhija, 2017). The experience that such firms have with taking over marketsupporting functions at home may thus be brought to the host economy, allowing them to navigate challenging environments and fill institutional voids, potentially with a positive impact on both home and host country (Cuervo-Cazurra and Genc, 2011). That is, from a sustainable development perspective, the key distinguishing factor of EMNE investment is the potential that progress on SDGs can be made in both the home and host country.

\section{Home- and host-country development: the SDGs}

Although most studies focus on the impact of foreign investment on the recipient country, it can also have a positive effect on the MNE's home country. Despite considerable progress in many emerging countries over recent years, much remains to be done. That is, sizeable gaps remain when we compare current indicators with targets embodied in the SDGs. For example, even in the rapidly growing economy of India, $21.3 \%$ of people lived on less than US\$1.90 a day in 2011. SDG 1, which reflects the aim to eradicate all forms of extreme poverty by 2030, is therefore particularly relevant, also considering the potentially promising role that outward investment can play in attaining such goals (Narula and Dunning, 2000). China, for example, has made remarkable gains by lifting more than 500 million of its citizens out of extreme poverty over the last three decades (UNDP, 2016).

Yet, similar to the situation of inward investment as outlined in section 2, conditions need to be right for lasting gains to materialize (for a review, see Blomström and Kokko, 1998). That is, not all home countries necessarily benefit from FDI outflows, as evidenced by Taiwan Province of China, where outward FDI seems to have negatively affected the poorest $20 \%$ of the population (Tsai and Huang, 2007). 
For outward FDI to have a positive effect on the home economy, MNEs should not relocate value-adding activities away from their home base upon the acquisition of new technologies or strategic assets, nor fully appropriate productivity spillovers themselves (Blomström and Kokko, 1998). Positive effects are more likely to materialize when the investment allows MNEs to specialize in the production of highvalue or high-tech intermediates, expand research and development activities at home, or when it gives room for the establishment of training institutes or specialized business service firms that would otherwise not have a reason to exist (Blomström and Kokko, 1998). Thus, when conditions are right, outward foreign investment can alleviate poverty, spur economic growth and create decent work opportunities both at home and abroad, in line with subgoals laid out under SDG 1 and SDG 8. As the discussion below indicates, other promising areas include infrastructure development and the improvement of market-supporting institutions, thereby bringing into focus SDG 9 and SDG 16, respectively. Whereas it is likely that host countries are the main benefactors in terms of infrastructure development, foreign investment might bring about gains for both countries with respect to the upgrading of institutions.

However, considering the inconclusive nature of the FDI-development literature, it may be difficult to find situations in which the conditions for development are met in both the home and host country at the same time (for a review, see Narula, 2014). Concerns may thus arise about the possibility that gains will not be equitably shared or that potential is left unrealized in one of the countries. Such worries are fuelled by active home governments that seek to encourage the type of investment that supplies natural resources to the home economy (Luo, Xue, and Han, 2010). Indeed, it is difficult to erase the popular perception that Chinese investment in Africa is rather short-lived, aimed at extracting natural resources, relatively low-tech and not deeply embedded, thereby mainly benefiting the investor country (Shen, 2015). Contrary to such a belief is the tentative evidence drawn from case studies, which highlight the often positive role that Chinese MNEs take as infrastructure financiers (e.g., Van Dijk, 2009; Shen, 2015). Thus, rather than observing that benefits are skewed in one direction, it may be the case that EMNEs' foreign investment serves the development of both the home and host country, although often subject to certain conditions (cf. Kaplinsky and Morris, 2009).

\section{Five areas of policy action: a research agenda}

Reflecting on the presented streams of literature as well as tentative evidence, I derive five conditions that are potentially important in allowing home and host countries to make simultaneous progress on SDGs, even though the effects of such conditions remain largely unstudied. These factors are presented in this section, together with a research agenda, which aims to verify anecdotal evidence and suggest areas of policy action that require further research. 


\subsection{Long-term investment projects}

Measures implemented with the aim of encouraging investments to be long-term may have potential benefits not only for the developing countries that receive such investment but also for the home countries from which firms internationalize. That is, when a firm undergoes a process of international expansion, more staff will typically be needed to coordinate a larger and more complex network of international operations (Meyer, Mudambi and Narula, 2011). Considering that the majority of such jobs are in support of functions under the control of a firm's headquarters, they are likely to be based in its home country.

Huawei, a Chinese manufacturer of networking and telecommunications equipment, initiated a growth strategy that was focused on expansion into developing countries first, followed by entry into developed economies (Accenture, 2008). As a sign of its remarkable success, the company grew its employee base from 24,000 by the end of 2005 to over 180,000 in 2016 , of which more than $70 \%$ are located at home. The additional employment that is created through the processes of internationalization will likely involve activities for which relatively skilled employees are needed, such as IT professionals, analysts and mid-tier managers. Currently, 80,000 of Huawei's employees are engaged in R\&D, many of which at research centres in China (Huawei, 2017). Moreover, middle management is developed through elaborate schemes of expatriation, as evidenced by the large number of Chinese expatriates at Huawei's foreign subsidiaries. At Huawei's Turkish and Indian subsidiary, for example, 20\% to $30 \%$ of the workforce is Chinese (Smith and Zheng, 2016). Therefore, outward investment could bring about progress on SDG 8 in particular, which seeks to stimulate the creation of decent work.

However, firms are known to expand their headquarters operations primarily under conditions of stability (Sirmon, Hitt and Ireland, 2007). The type of foreign investment that is followed by rapid divestment is unlikely to have a lasting effect on a firm's home base. Yet, most governments have measures in place that aim to attract FDI rather than encourage it to stay in the country for a prolonged period of time (Zhan and Karl, 2016). Frequently used measures such as tax breaks could also be made conditional on the time that a firm stays in a country, thereby giving it an incentive to become more embedded and grow operations both at home and abroad. Scholars should aim to address what effect the longevity of investment projects can have on the creation of decent work opportunities both at home and abroad. If a positive relationship indeed does exist, additional research can be directed at finding out what time period would be long enough for mutual benefits to materialize, as well as verifying if the relationship is potentially non-linear. From a policy standpoint, research can address what measure would be most effective in stimulating investments to be more long-term, thereby considering such measures as tax breaks, the development of infrastructure and education schemes. 


\subsection{Partnerships between home- and host-country firms}

The involvement of home-country suppliers or partners in the outward foreign investment projects of EMNEs, combined with the creation of partnerships with local firms, could improve the likelihood that both home and host countries benefit in terms of development. As firms typically do not operate in isolation, important events such as foreign investment will likely have significant consequences for the partner companies with which a firm cooperates in the home country, potentially causing sizeable spillover effects (Blomström and Kokko, 1998). Suppliers may benefit from an increase in orders from abroad, and, subsequently, experience with exporting. Partner distributors in the home country may seek to exploit connections with the investing firm by expanding abroad themselves.

However, such episodes of simultaneous internationalization could crowd out local suppliers and distributors, as they would be in direct competition and often possess fewer skills and firm-specific resources (Javorcik and Spatareanu, 2011). Rather than allowing unrestricted entry of home-country partners, governments in host countries could set as a requirement that joint ventures are created with local firms and stimulate the creation of linkages through this form of shared ownership (Lauridsen, 2004; Javorcik, 2004). For example, home-country distributors could partner up with local distributors to both serve the investing EMNE, whereby the former set of firms gains valuable market and internationalization knowledge. Moreover, such firms may be exposed to new opportunities otherwise left unexploited, learn from experiences and benefit from the pooling of resources in joint venture partnerships (cf. Chetty and Blankenburg Holm, 2000). In turn, local distributors may benefit from the knowledge and skill sets that both foreign firms bring to the host economy (Javorcik and Spatareanu, 2009). Such spillovers are likely to have the largest impact on SDG 1 and SDG 8 in particular, as the resulting increase in organizational efficiency will allow these small and medium enterprises to pay higher wages (Maksimov, Wang and Luo, 2017).

The beneficial impact of supplier partnerships is illustrated by the example of Hyundai. In 1997, the Korean car manufacturer set up its largest overseas assembly factory in India by means of a greenfield investment. Soon after, many of the major suppliers that were also based in the Ulsan automobile cluster in Korea followed Hyundai to India. Oftentimes they partnered with local Indian firms in joint ventures, which contributed to Hyundai Motors India becoming the company's first self-sufficient manufacturing unit, with 85\% of the content produced in India (Park, 2004; Akyut and Goldstein, 2007).

Future research should address whether such experiences are more common and under what conditions both home and host countries can benefit from supplier partnerships. In Belarus, for example, a car assembly factory is being completed by BelGee, a Belarusian-Chinese joint venture. The owners of BelGee include Belarusian 
manufacturer BelAZ, Chinese automotive company Geely and another BelarusianChinese joint venture specialized in the production of automobile parts. With the use of Chinese technology, 120,000 passenger cars of the Geely brand are projected to be produced annually. By mid-2018, 50\% of the parts used in the assembly process will need to be produced locally in Belarus, with the remainder likely supplied by Geely's partners in China (CTV, 2017).

In addition to studying such cases in greater detail, future research should aim to uncover the main source of benefits to home-country partners. With potential advantages ranging from better opportunity recognition to internationalization knowledge, such benefits may be more intangible than the expected efficiency gains for host-country firms. Moreover, it can be studied whether benefits also materialize if host-country governments adopt a more lenient stance and stimulate the formation of shared ownership ventures, rather than set binding requirements - for example, with the use of tax breaks.

\subsection{Mutually supporting GVC roles}

The home and host country could each potentially benefit from the outward investment of EMNEs when they move towards a new GVC structure in which each of the newly assumed roles are in mutual support of one another. That is, industrial policy aimed at creating a role for firms in GVCs may not only benefit companies in the specific host economy, but also the EMNEs that invest there. Both sets of firms could benefit when a mutually reinforcing dynamic can be brought about that will stimulate investors to become GVC leaders and developing-economy firms to be vital partners within that chain. When the investment project also involves home-country suppliers, in line with suggestions made previously, it is likely that the proposed shared-ownership ventures with local firms will be in the best position to take on the latter role. That is, they can likely draw on synergistic advantages in the form of superior network knowledge. Although MNEs from developed economies control most GVCs, EMNEs are increasingly on their way to take on GVC leadership (Altenburg, Schmitz and Stamm, 2008; Gereffi, 2014). For developing-economy firms, it may prove to be easier to carve out their place in value chains that are subject to change, as opposed to other chains in which firms already take on clearly defined roles for a prolonged period of time.

Both home- and host-country governments could recognize the changing competitive landscape as an opportunity to coordinate policy and help firms in each of the countries assume new roles in GVCs. Home-country governments of emerging economies could, for example, enhance national innovative capacity through hightech international trade and inward FDI (Wu, Ma and Zhuo, 2017). Host-country governments can prioritize the cultivation of industries that best support these new centres of innovative capacity (Narula and Dunning, 2010). Whereas home countries 
of EMNEs can benefit from the stability and innovation that is associated with a coordinating role, developing economies have an opportunity to upgrade in both social and economic terms by linking into global value chains (Lee and Gereffi, 2015).

Although the use of industrial policy in relation to development has been studied, as well as advocated (e.g., Narula, 2014), more research is needed to assess the dynamic aspects of two countries undergoing changes simultaneously. Future studies should aim to establish if both developing and emerging economies can benefit equally when firms in certain industries assume new roles. Moreover, additional research could study the process of opportunity recognition in host countries when governments pick industries that best support fledgling innovation centres in emerging economies.

\subsection{Simultaneous upgrading of institutions}

EMNEs' foreign investment could also set in motion a process of institutional upgrading in both the home and host country when the experience that such firms have with overcoming institutional voids is transferred to the host environment. Both countries could then potentially make progress on SDG 16, which aims to promote peace, justice and strong institutions. Such potential relates to EMNEs' betterdeveloped capability to cope with challenging institutional environments through the internalization of transaction-supporting functions, as described above.

Not only do EMNEs face the challenge of performing well in their home country despite these difficulties, they also need to cope with the oftentimes poor reputation that firms from emerging economies have regarding their environmental, ethical and business standards (Marano, Tashman and Kostova, 2017). In response, EMNEs increasingly attempt to align themselves with global meta-norms and expectations about MNE behaviour (Kostova, Roth and Dacin, 2008). The adoption of corporate social responsibility (CSR) measures is one way in which EMNEs signal their intent to conform to global expectations (Marano et al., 2017). In a similar vein, EMNEs need to internalize behaviour that conforms to globally accepted business standards, and to signal transparency, accountability and reliability as they aim to become important players on the world stage. To that end, such firms can partially rely on their experience with superior institutions from prior ventures to developed economies. This, in turn, has already contributed to the upgrading of institutions in their respective home countries (Hoskisson et al., 2013).

In an ever more closely knit and transparent world economy, EMNEs also need to be consistent in maintaining standards when they invest in developing economies. For example, the Brazilian firm Rio Tinto faced serious backlash when accused of bribery and corruption in connection with the acquisition of mining rights in Guinea, leading to the sacking of two top executives (Economist, 2017). By contrast, exemplary behaviour in developing countries may be beneficial for a firm in overcoming 
legitimacy challenges, as evidenced by the case of Odebrecht, a Brazilian MNE (Doh, Littell and Quigley, 2015). Indeed, especially in countries characterized by weaker institutions, CSR can be used as a strategic tool to generate goodwill and forge strong relationships (El-Ghoul, Guedhami and Kim, 2017; Doh et al., 2017). For example, Odebrecht, the largest construction and engineering conglomerate in South America, has valued sustainability policies since its inception, applying them in over 35 countries, many of which are developing economies. Its policies aimed at, for example, waste reduction and the provision of basic health care and education, not only help develop local communities, but also increase growth opportunities for the company itself (Doh et al., 2015: 116).

Methods that EMNEs adopt to conform to global meta-standards could be transferred, either directly or indirectly, to firms in the developing country in which they invest. That is, such host-country firms may learn from the skill sets that EMNEs have in navigating challenging institutional environments and internalizing expectationconforming behaviour. As there is potential to learn from experiences developed in a more similar context, recipient countries may undergo a smoother upgrade of those institutions through interactions with EMNEs and their governments, as opposed to developed-economy representatives. Whereas the host country can become a more attractive destination for future FDI projects, the home country of EMNEs may also benefit from having firms in their economy that are more resilient as a result of their experience with varying degrees of institutional quality as well as institutional change.

As both institutional change and the way in which EMNEs engage in signaling behaviour are relatively recent phenomena, research is at an early stage. Scholars may, however, be guided both by this discussion and by the pioneering work by Marano et al. (2017), as they aim to uncover if and to what extent the home and host country can mutually upgrade their institutions. Specifically, future efforts could be aimed at the progress that is made on SDG 16 and thereby establish whether institutions have become more effective and inclusive. In addition, scholars are advised to study what experiences are more easily transferable to host-country settings. Moreover, the interaction between recent policy changes and EMNEs' adoption of signaling behaviour is relevant when considering such a transfer of experiences, now that governments of emerging countries gradually pay more attention to environmental as well as business standards at home (cf. May, 2013).

\subsection{Conditional policy and infrastructure development}

Policy that ties incoming FDI projects to certain conditions could be shaped to serve the interests of both home and host countries. If formulated sensibly, thereby not deterring potential investors, such measures could connect the right to access hostcountry (natural) resources with requirements that need to be met by EMNEs in return. For example, investment in local infrastructure such as roads and railways 
could be made an explicit condition that needs to be fulfilled in order to receive approval for a specific foreign investment project. Home-country governments thereby benefit by obtaining natural resources not available in the home economy, while host developing countries could make substantial progress on SDGs related to infrastructure development, particularly SDG 9.

In this fashion, host countries can take advantage of the expertise that EMNEs bring with them in terms of organizing infrastructure projects. That is, such firms are often seen to absorb the costs of absent institutions in their home countries by substituting for the state in building infrastructure (Banerjee, Oetzel and Ranganathan, 2006; Boddewyn and Doh, 2011; Doh et al., 2017). The investing firm, in turn, also has an interest in the organization of such projects, as it can make sure that good infrastructure is built in line with its own needs. For instance, countries in Sub-Saharan Africa already benefit considerably from China's growing role as infrastructure financier but could channel efforts to construct more innovative deals and improve on that potential (Foster et al., 2009). For example, Chinese and Zambian officials have worked together to establish the Economic and Trade Cooperation Zone, providing Chinese investors with favourable tax conditions and opportunities to develop good infrastructure. CNMC, a large Chinese mining firm, has subsequently purchased the Chambishi mine in that area, a move it would probably not have made otherwise (Bastholm and Kragelund, 2009).

More research is needed to study the effect of conditional policy measures on home countries' ability to make progress on SDG 9. Specifically, what is defined as the "right" balance between setting conditions and not deterring potential investors needs to be studied. Moreover, even though home countries can potentially benefit from stable access to resources through tailored infrastructure development, research needs to address to what extent both countries are able to make sustainable development gains.

\section{Concluding remarks}

There is considerable potential for foreign investment to positively affect both the home country from which an EMNE internationalizes and the host country that receives its investment. Such investment may potentially leave a lasting effect on economic growth, create decent work opportunities, alleviate poverty and contribute to the upgrading of institutions and infrastructure. Rather than accepting that development gains are unequally distributed or remain unrealized, governments and firms have an opportunity to coordinate policy that will create a mutually beneficial environment conducive to sustainable development. Five promising areas were highlighted where the interests of home and host countries possibly collide, in most cases guided by supporting policy measures. However, more research is needed to 
study these measures and the effect they can have on the progress that both home and host countries can make on the SDGs. In addition to the suggestions made for each separate area of policy action, scholars are also advised to pay attention to the interaction between the various measures and their combined effect on sustainable development.

\section{References}

Accenture (2008). Multi-polar world 2: the rise of the emerging-market multinational (London: Accenture).

Akyut, D., and Goldstein, A. (2007). "Developing country multinationals: South-South investment comes of age", in United Nations Department of Economic and Social Affairs, Industrial development for the 21st century: Sustainable development perspectives (New York: United Nations), pp. 85-116.

Altenburg, T., Schmitz, H., and Stamm, A. (2008). "Breakthrough? China's and India's transition from production to innovation”, World Development, 36(2), pp. 325-344.

Banerjee, S. G., Oetzel, J. M., and Ranganathan, R. (2006). "Private provision of infrastructure in emerging markets: Do institutions matter?", Development Policy Review, 24(2), pp. 175-202.

Barnes, J., and Morris, M. (2008). "Staying alive in the global automotive industry: What can developing economies learn from South Africa about linking into global automotive value chains?", European Journal of Development Research, 20(1), pp. 31-55.

Bastholm, A., and Kragelund, P. (2009). "State-driven Chinese investments in Zambia: combining strategic interests and profits", in M. P. van Dijk, ed., The new presence of China in Africa (Amsterdam University Press), pp. 117-140.

Bell, M., and Marin, A. (2004). "Where do foreign direct investment-related technology spillovers come from in emerging economies? An exploration in Argentina in the 1990s", European Journal of Development Research, 16(3), pp. 653-686.

Boddewyn, J., and Doh, J. (2011). "Global strategy and the collaboration of MNEs, NGOs, and governments for the provisioning of collective goods in emerging markets", Global Strategy Journal, 1(3-4), pp. 345-361.

Blomström, M., and Kokko, A. (1998). "Multinational corporations and spillovers", Journal of Economic Surveys, 12(2), pp. 1-31.

Castellani, D., and Zanfei, A. (2002). "Multinational experience and the creation of linkages with local firms: Evidence from the electronics industry", Cambridge Journal of Economics, 26(1), pp. 1-25.

CCSI (2016). Columbia Center on Sustainable Investment Emerging Market Global Players project, http://ccsi.columbia.edu/publications/emgp.

Chen, V. Z., and Johnson, L. (2013). "Emerging market MNEs and social responsibility: An institutional pressure perspective", Transnational Corporations, 22(3), pp. 1-4.

Chetty, S., and Blankenburg Holm, D. (2000). "Internationalisation of small to medium-sized manufacturing firms: A network approach”, International Business Review, 9(1), pp. 77-93. 
CTV - Belarusian Television Channel (2017). Belgee Company, http://en.ctv.by/en/belgeecompany.

Cuervo-Cazurra, A., and Genc, M. (2008). "Transforming disadvantages into advantages: Developing-country MNEs in the least developed countries", Journal of International Business Studies, 39(6), pp. 957-979.

Cuervo-Cazurra, A., and Genc, M. (2011). "Obligating, pressuring, and supporting dimensions of the environment and the non-market advantages of developing-country multinational companies", Journal of Management Studies, 48(2), pp. 441-455.

Doh, J., Littell, B., and Quigley, N. R. (2015). "CSR and sustainability in emerging markets: Societal, institutional, and organizational influences", Organizational Dynamics, 44(2), pp. 112-120.

Doh, J., Rodrigues, S., Saka-Helmhout, A., and Makhija, M. (2017). "International business responses to institutional voids", Journal of International Business Studies, 48, pp. 293307.

Economist (2017). "A pig of a project: Africa's largest iron-ore deposit has tainted all who have touched it”, January 12, http://www.economist.com/news/business/21714388billionaires-and-big-companies-have-come-cropper-one-worlds-poorest.

El-Ghoul, S., Guedhami, O., and Kim, Y. (2017). "Country-level institutions, firm value, and the role of corporate social responsibility initiatives", Journal of International Business Studies, 48, pp. 360-385.

Foster, V., Butterfield, W., Chen, C., and Pushak, N. (2009). Building bridges: China's growing role as infrastructure financier for Sub-Saharan Africa (Washington DC: World Bank Publications).

Gereffi, G. (2014). "Global value chains in a post-Washington Consensus world", Review of International Political Economy, 21(1), pp. 9-37.

Giroud, A. (2012). "Mind the gap: How linkages strengthen understanding of spillovers", European Journal of Development Research, 24(1), pp. 20-25.

Giuliani, E., Pietrobelli, C., and Rabellotti, R. (2005). "Upgrading in global value chains: Lessons from Latin American clusters", World Development, 33(4), pp. 549-573.

Guillén, M. F., and Garcia-Canal, E. (2009). "The American model of the multinational firm and the 'new' multinationals from emerging economies", Academy of Management Perspectives, 23(2), pp. 23-35.

Hemphill, T. A., and White, G. O. (2013). "China's national champions: The evolution of a national industrial policy-or a new era of economic protectionism?", Thunderbird International Business Review, 55(2), pp. 193-212.

Huawei (2017). Annual reports 2006 through 2016. http://www. huawei.com/en/about-huawei/ annual-report.

Hoskisson, R. E., Wright, M., Filatotchev, I., and Peng, M. W. (2013). "Emerging multinationals from mid-range economies: The influence of institutions and factor markets”, Journal of Management Studies, 50(7), pp. 1295-1321.

Javorcik, B. S. (2004). "Does foreign direct investment increase the productivity of domestic firms? In search of spillovers through backward linkages", American Economic Review, 94(3), pp. 605-627. 
Javorcik, B. S., and Spatareanu, M. (2009). "Tough love: Do Czech suppliers learn from their relationships with multinationals?", The Scandinavian Journal of Economics, 111(4), pp. 811-833.

Javorcik, B. S., and Spatareanu, M. (2011). "Does it matter where you come from? Vertical spillovers from foreign direct investment and the origin of investors", Journal of Development Economics, 96(1), pp. 126-138.

Kaplinsky, R., and Morris, M. (2009). "Chinese FDI in Sub-Saharan Africa: Engaging with large dragons", European Journal of Development Research, 21(4), pp. 551-569.

Khanna, T., and Palepu, K. (2006). "Emerging giants: Building world-class companies in developing countries”, Harvard Business Review, 84, pp. 60-69.

Kolk, A. (2016). "The social responsibility of international business: From ethics and the environment to CSR and sustainable development", Journal of World Business, 51(1), pp. 23-34.

Konara, P., and Wei, Y. (2016). "Foreign direct investment as a catalyst for domestic firm development: The case of Sri Lanka", Transnational Corporations, 23(3), pp. 1-32.

Kostova, T., Roth, K., and Dacin, M.T. (2008). "Adoption of an organizational practice by subsidiaries of multinational corporations: Institutional and relational effects", Academy of Management Journal, 45(1), pp. 215-233.

Lall, S., and Narula, R. (2004). "FDI and its role in economic development: Do we need a new agenda?", European Journal of Development Research, 16(3), pp. 447-464.

Lauridsen, L. S. (2004), "Foreign direct investment, linkage formation and supplier development in Thailand during the 1990s: The role of state governance", European Journal of Development Research, 16(3), pp. 561-586.

Lee, J., and Gereffi, G. (2015). "Global value chains, rising power firms and economic and social upgrading", Critical perspectives on international business, 11(3/4), pp. 319-339.

Lorentzen, J. (2005). "The absorptive capacities of South African automotive component suppliers", World Development, 33, pp. 1153-1182.

Luo, Y., and Tung, R.L. (2007). "International expansion of emerging market enterprises: A springboard perspective", Journal of International Business Studies, 38, pp. 481-498.

Luo, Y., Xue, Q., and Han, B. (2010). "How emerging market governments promote outward

FDI: Experience from China". Journal of World Business, 45(1), pp. 68-79.

Maksimov, V., Wang, S. L., and Luo, Y. (2017). "Reducing poverty in the least developed countries: The role of small and medium enterprises", Journal of World Business, 52(2), pp. 244-257.

Marano, V., Tashman, P., and Kostova, T. (2017), "Escaping the iron cage: Liabilities of origin and CSR reporting of emerging market multinational enterprises", Journal of International Business Studies, 48(3), pp. 386-408.

May, K. (2013). "Chinese agricultural overseas investment: Trends, policies and CSR", Transnational Corporations, 22(3), pp. 43-74.

Meyer, K. E., Mudambi, R., and Narula, R. (2011). "Multinational enterprises and local contexts: the opportunities and challenges of multiple embeddedness", Journal of Management Studies, 48(2), pp. 235-252. 
Narula, R. (2014). "Foreign direct investment as a driver of industrial development: Why is there so little evidence?" in R. van Tulder, A. Verbeke, and R. Strange, eds., Progress in International Business Research, Volume 8, International Business and Sustainable Development (Emerald Group Publishing Limited), pp. 45-67.

Narula, R., and Driffield, N. (2012). "Does FDI cause development? The ambiguity of the evidence and why it matters", European Journal of Development Research, 24(1), pp. 1-7.

Narula, R., and Dunning, J. H. (2000). "Industrial development, globalization and multinational enterprises: New realities for developing countries”, Oxford Development Studies, 28(2), pp. 141-167.

Narula, R., and Dunning, J. H. (2010). "Multinational enterprises, development and globalization: Some clarifications and a research agenda", Oxford Development Studies, 38(3), pp. 263287.

Park, J. (2004). "Korean Perspective on FDI in India", Economic and Political Weekly, 31, pp. $3551-3555$.

Shen, X. (2015). "Private Chinese investment in Africa: Myths and realities", Development Policy Review, 33(1), pp. 83-106.

Sirmon, D. G., Hitt, M. A. and Ireland, R. D. (2007). "Managing firm resources in dynamic environments to create value: Looking inside the black box", Academy of Management Review, 32(1), pp. 273-292.

Smith, C., and Zheng, Y. (2016). "The management of labour in Chinese MNCs operating outside of China: A critical review", in M. Liu and C. Smith, eds., China at work: A labour process perspective on the transformation of work and employment in China (Palgrave Macmillan), pp. 361-388.

Tsai, P. L., and Huang, C. H. (2007). "Openness, growth and poverty: The case of Taiwan", World Development, 35(11), pp. 1858-1871.

UNCTAD (2016). World investment report 2016: investor nationality: policy challenges (New York and Geneva: United Nations).

UNDP (2016). The living standards dimension of the human development index: Measuring poverty with big data in China (China: United Nations Development Programme).

Van Dijk, M. P. (2009). The new presence of China in Africa (Amsterdam: Amsterdam University Press).

Wang, C., Hong, J., Kafouros, M., and Wright, M. (2012). "Exploring the role of government involvement in outward FDI from emerging economies", Journal of International Business Studies, 43, pp. 655-676.

Williamson, P. J., and Raman, A. P. (2011). "How China reset its global acquisition agenda", Harvard Business Review, 89(4), pp. 109-114.

Wu, J., Ma, Z., and Zhuo, S. (2017). "Enhancing national innovative capacity: The impact of high-tech international trade and inward foreign direct investment", International Business Review, 26(3), pp. 502-514.

Zhan, J., and Karl, J. (2016). "Investment incentives for sustainable development", in A. T. Tavares-Lehmann, P. Toledano, L. Johnson and L. Sachs, eds., Rethinking investment incentives: trends and policy options (New York: Columbia University Press), pp. 204-227. 